\title{
Report on the Surface Drift of the English Channel and neighbouring Seas during 1897.
}

\author{
By
}

Walter Garstang, M.A.,

Naturalist in charge of Fishery Investigations, M.B.A.

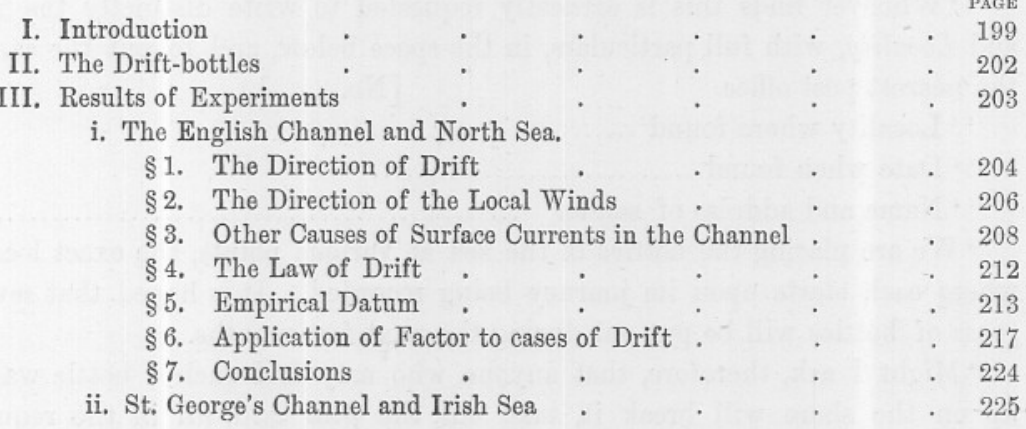

\section{Introduction.}

Some eighteen months ago the Director of the Plymouth Laboratory of the Marine Biological Association decided to carry out a series of investigations concerning the surface currents of the English Channel at different seasons of the year, and for a series of years, by means of properly devised floating bodies which would attract attention when stranded on the shore, and the recovery of which could without difficulty be recorded. At the commencement of the investigation $\mathrm{Mr}$. Allen communicated his scheme to the editors of the west-country Press, and these gentlemen kindly gave publicity to the plan, the success of which depended very largely upon the co-operation of residents and visitors frequenting the sea-shore. Mr. Allen's letter expresses so clearly the object and method of the investigation, that I cannot do better than reproduce it here:- 


\section{"THE DRIFT OF FLOATING FISH-EGGS IN THE CHANNEL.}

"January 27 th, 1897.

"SIR,-I should be obliged if through the medium of your paper you would be good enough to give publicity to a series of experiments which have just been commenced by the Marine Biological Association, with a view to determine the direction of the drift of floating bodies in the western part of the English Channel. The experiments are of such a nature that any of your readers, who either from business or pleasure frequent the sea-shore, may be able to assist materially in their successful completion.

"We are preparing a large number of ordinary egg-shaped soda-water bottles, weighted with shot in such a way that they float vertically in seawater, with only a very small portion of the neck exposed. In each bottle a stamped and numbered post card is placed, and the bottle is corked and sealed. Each post card has the following notice upon it :-

\section{"For Scientific Enquiry into the Currents of the Sea.}

" "Whoever finds this is earnestly requested to write distinctly the Date and Locality, with full particulars, in the space below, and to put the card in the nearest post office.

" "Locality where found [No. ]

" "Date when found

" "Name and address of sender

"We are placing the bottles in the sea at various points, the exact locality where each starts upon its journey being recorded. It is hoped that several gross of bottles will be put out during the next few months.

"Might I ask, therefore, that anyone who may find such a bottle washed up on the shore will break it, take out the post card, fill in the required information, and put the card in the nearest post office?

"Teachers in the schools of the various towns and villages along the south coast could do us a great service by asking their boys to look out for the bottles, and in case of any being found, seeing that the post cards were correctly filled in.

"It might interest your readers if I explain shortly the reason for making these experiments. It is now a well-known fact that the majority of the food-fishes spawn in the sea at some distance from the coast, and that the eggs float in the water. These floating eggs are carried about by the currents for some considerable time before they are hatched, and the little fish (larva), when it leaves the egg, is still so small and light that it is at the mercy of the wind and waves. Now it is a fact that although the fish generally spawn at some distance from the coast, the young fish are usually found close inshore. This is particularly the case with flat-fishes. For instance, there are important spawning grounds for plaice south-east of the Eddystone, whilst young plaice, under one inch long, are found only in shallow water in sandy bays or estuaries, such as Whitsand Bay or the mouth of the river Exe. These very young fish have probably been brought ashore by currents, when 
they were floating eggs or larvæ carried about by the sea. It is very important, therefore, to know the direction of these currents, in order that we may be able to tell where the eggs from the fish spawning upon any particular ground will be carried. At present we do not know whether the eggs from the plaice spawning on the Eddystone grounds are carried towards Plymouth and Whitsand Bay, or whether they are carried eastward towards some point on the Devonshire coast, or westward to the coast of Cornwall. Upon questions of this kind our experiments should throw light.

"Investigations of a similar kind have been made in the Irish Sea by Professor Herdman, and in the North Sea by the Scottish Fishery Board. In the case of the experiments in the Irish Sea, about 35 per cent. of the bottles put out were found and the post cards properly filled up and returned, whilst in the case of the North Sea experiments from 20 to 30 per cent. were recovered. The latter experiments showed that the inshore waters of the Firth of Forth and St. Andrews Bay derive their main supplies of young fish, not from the waters lying contiguous to them to the eastward, but from areas further north, such as the spawning grounds off the Bell Rock and those of the Forfarshire coast. It was also shown that a southerly current runs down the eastern side of Scotland and England to the coast of Norfolk, where it turns to the eastward and crosses the North Sea. Of the bottles set free off the east coast of Scotland many were picked up on the east coast of England as far south as Norfolk, but none further south than this. Many were, however, carried across the North Sea and found on the coasts of Schleswig and Jutland. This will explain the immense nurseries of young fish which are found in the eastern portions of the North Sea-the so-called 'Eastern Grounds,' so well known from the large number of immature flatfish which are trawled there.

E. J. Allen.

"Marine Biological Association, Plymouth."

It will be seen in the sequel that Mr. Allen's experiments to determine the currents in the neighbourhood of the Eddystone grounds have provided data not only for the settlement of these local problems of importance to the west-country fisheries, but for determining many matters connected with the surface currents of all the three seas which wash the shores of England. The majority of the bottles put overboard near the Eddystone have been recovered on the south coast, along the whole length of the English Channel; but a very large number have made a safe passage through the Straits of Dover, stranding eventually on the shores of Holland, Germany, Denmark, Sweden, and Norway; a few have rounded the Land's End and travelled as far as Barnstaple Bay; and others put out in the Irish Sea and St. George's Channel have stranded on the west coasts of England, Wales, and Scotland, even so far to the northward as the Isle of Colonsay in the Firth of Lorne. 
Most of the drift-bottles have been put overboard in the neighbourhood of the Eddystone by different members of the scientific staff of the Marine Biological Association in the ordinary course of their trawling and dredging excursions; but, as the Busy Bee is incapable of making long journeys far from land, we have always been glad to accept the services of others who have kindly come to our assistance in this part of the work. We are under a particular debt of gratitude to Admiral the Hon. Sir E. R. Fremantle, K.C.B., C.M.G., in this connection. He very kindly permitted the distribution of a number of the bottles among the torpedo-boat destroyers cruising from Devonport, and to him, to Commander Shirley, of H.M.S. Decoy, and to the commanding officers of H.M.S. Lynx, H.M.S. Skate, H.M.S. Sunfish, H.M.S. Opossum, and H.M.S. Ferret, we desire to express our warm thanks for the material assistance they rendered us in this part of the work.

We are also indebted to H. E. M. Studdy, Esq., and other yachtsmen, for similar assistance kindly given us.

It gives us particular pleasure to thank the officers and boatmen of H.M. Coastguard at innumerable points along the coast for the promptitude with which they have returned the post cards to us upon the recovery of any bottles. We owe a very considerable number of our records to the vigilance of the members of this efficient branch of the service.

We desire also to thank the numerous private individuals and fishermen, both home and foreign, who have increased the value of these experiments by properly inscribing and returning the post cards contained in bottles they have found, and for the information they have always been willing to convey in reply to our inquiries.

For the meteorological work of this report I have received valuable data from Edward Kitto, Esq., Superintendent of the Falmouth Observatory ; C. E. Peek, Esq., Superintendent of the Rousdon Observatory, Lyme Regis; Alfred Chandler, Esq., Borough Meteorologist, Torquay; and H. Victor Prigg, Esq., Meteorologist to the Borough of Plymouth. To these gentlemen I beg to convey my warm thanks for their assistance, which has been generously given.

\section{The Drift-Bottles.}

Various objects have been employed by different investigators in their experiments upon surface currents. The Prince of Monaco employed small floating vessels of copper, specially prepared, but their fitness to indicate accurately the course of surface currents has been criticised owing to the ease with which they could be propelled at the surface of the water by the direct action of the winds. Any small 
buoyant object of spherical and, still more so, of cylindrical form, floating at the sea-surface and bobbing up and down under the action of the waves, inevitably exposes a considerable part of its bulk to the direct action of the winds, and experiments founded upon the journeys of such objects are vitiated in proportion to the relative bulk of the part exposed to wind-action. Mr. Allen selected common "eggshaped" soda-water bottles (used by Schweppe and other manufacturers of aërated waters) for our experiments, and their admirable adaptability to the purpose will be generally conceded. These bottles are 9 inches long (varying between 9 inches and $9 \frac{1}{4}$ inches), and their maximum diameter is a little below the middle of the bottle, at $5 \frac{1}{2}$ inches from the mouth. From this zone the bottle tapers towards each extremity, being conical at the closed end, but produced into a cylindrical neck at the open end. This neck is $2 \frac{1}{2}$ inches long, and its diameter is 1 inch. The mouth is surrounded by a slight rim $\frac{3}{4}$-inch deep, which increases the outside diameter of the neck in this region to a maximum diameter varying between $1 \frac{1}{8}$ and $1 \frac{1}{4}$ inches.

The preparation of these common objects for their scientific mission is as follows:-The bottles are washed and thoroughly dried. A piece of wire, the counterpoise of the post card to be eventually enclosed, is inserted, a piece of hard paraffin is dropped inside, and small quantities of leaden shot are added until the bottle floats upright in sea-water, with its mouth all but submerged. The wire is then removed and the bottle placed upright in a pail of hot water until the paraffin is melted, when it is placed aside-still in a vertical position-until the paraffin has thoroughly hardened again. The object attained by this means is to prevent the shot from rolling about inside the bottle, and so displacing the centre of gravity. The post card and a conspicuous notice marked "Break the Bottle" are then introduced, and the bottle is thoroughly corked, the cork being pushed in flush with the mouth of the bottle and sealed with paraffin wax. The whole of the neck and upper half of the bottle is then painted with red enamel paint, so as to render the bottle conspicuous.

\section{Results of Experiments.}

The actual localities where our bottles have been sent adrift and where they have been subsequently recovered are given in tabular form at the end of this report. The experiments fall into two categories dealing with distinct areas, viz.: (1) the English Channel and North Sea, and (2) St. George's Channel and the Irish Sea. Only NEW SERIEs,-vol, v. No. 2. 
the former group of experiments approaches completeness, and in the subsequent discussion of the results I shall deal more particularly with this area.

In the course of the year 430 bottles were sent adrift in 53 batches in the English Channel, and 117 bottles belonging to 40 batches have been recovered up to the present time (Feb. 28, 1898). Thus $27 \%$ of the bottles, or rather less than one-third, have been recovered from the Channel lots.

In the Irish Sea and St. George's Channel 36 bottles were sent adrift in 6 batches, all on the 30th of March, and 20 bottles, representing all six batches, have been recovered. This gives the high percentage of 55 , or rather more than half of the total number put out.

The total percentage of recoveries from both areas combined is $29 \cdot 4 \%$.

\section{The English Channel and North Sea.}

$\S 1$. The Direction of Drift.-The general direction and rate of the surface drift in this area are well seen by reference to Table I., batch no. III. Out of 27 bottles sent adrift near the Eddystone in the latter part of January, 10 have been recovered, and these were picked up at places successively further away to the E. and N.E., the only break in the sequence being the recovery of a bottle at Terschelling on August 15th, twelve days after a bottle had been found at Schiermonnikoog, 40 miles to the eastward. The general rate of drift is seen from the table to be about 3 miles a day, which yields about 90 miles a month. Fjellbacka, on the west coast of Sweden, was reached in October-a distance of over 900 miles-in little more than nine months.

The regularity of this drift to the north-eastward is, however, frequently departed from; for example, out of six bottles sent adrift off the Lizard on March 31st (batch no. XXX.) two bottles were picked up at Sennen Cove, situated round the corner of Land's End, on April 6th-a journey of 35 miles to the westward in six days, at an average rate of nearly six miles a day.

Again, a drift may begin in one direction and end in another, as is shown very clearly by batch no. XL. In this case bottles put out

- near the Eddystone on May 11th went westwards to Mounts Bay, arriving at Penzance on June 2nd; they then rounded the Land's End and arrived at Croyde, on the north coast of Devon, three weeks later. Here their progress appears to have been arrested, and apparently a retrograde movement set in, for on August 20th a bottle was picked up at Bude, in North Cornwall, and-still more remarkable-another was recovered at Eastbourne three months later. 
The general features of the direction of drift throughout the year may conveniently be summarised by plotting out for each successive month the number of batches recovered to eastward or westward of their position in the preceding month. The following table contains the results of an analysis of this kind for the English Channel, the North Sea records being for the present omitted :-

\section{Monthly Summary showing the direction taken by drift-bottles in the English Channel, 1897.}

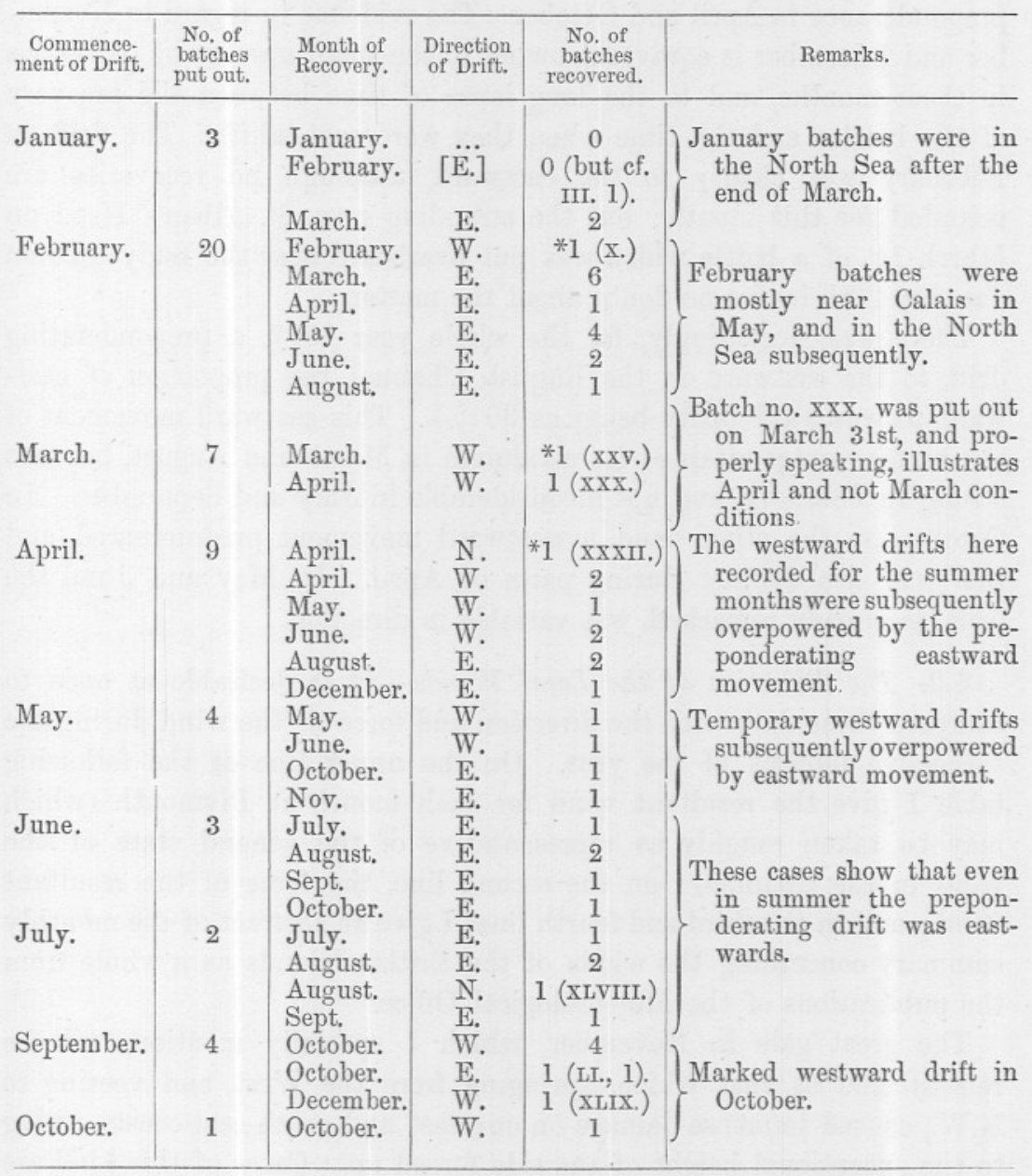

* These drifts were of very short duration (only one day each).

If now we condense this summary into a statement of the aggregate number of westward and eastward drifts for each month in the year 
(neglecting, however, the three cases of drifts not exceeding twentyfour hours' duration) we obtain the following results :-

Direction. Jan. Feb. Mar. Apr. May June July Aug. Sept. Oct. Nov. Dec. Total. $\begin{array}{llllllllllllll}\text { Westward. - } & 0 & 0 & 3 & 2 & 3 & 0 & 0 & 0 & 5 & 0 & 1 & \ldots & 14\end{array}$

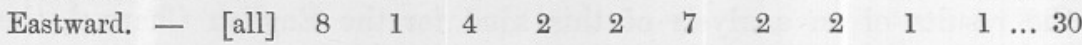

This table shows that the surface drift was markedly to the eastward in March and August, and also to the eastward, although not so conspicuously so, in July and September. The drift was variable in direction in April, May, June, and October, with a marked westward preponderance in April and October. The evidence in regard to November and December is equivocal, owing to the small number of recoveries in these months, and to the long lapse of time between the recovery of the bottles and the time when they were sent adrift. The drift in February was clearly to the eastward, although no recoveries are recorded for this month; but the stranding near St. Alban's Head on March 1st of a bottle which was put overboard near the Eddystone on January 29th leaves no doubt about the matter.

There was, accordingly, for the whole year 1897, a preponderating drift to the eastward in the English Channel, the proportion of eastward to westward drifts being as $30: 14$. This eastward movement of the surface water attained its maximum in March and August, but was strong in February, and not inconsiderable in July and September. In October, on the other hand, a westward movement predominated, and this was also distinct during parts of April. In May and June the drift, as already remarked, was variable in direction.

$\S 2$. The Direction of the Local Winds.-It is desirable at once to compare these data with the direction and force of the wind during the successive months of the year. On the upper line of the following table I give the resultant wind for each month at Plymouth (which may be taken roughly as representative of the general state of the wind in the Channel); on the second line, the force of the resultant wind; and in the third and fourth lines I give an abstract of the monthly summary concerning the winds of the British Islands as a whole from the publications of the Meteorological Office.

The great gale in November, which I specially mention, will be remembered as that which, springing from the West, and veering to N.W., caused immense damage on our east and south-east coasts, owing to the exceptional height of the tide forced up. Cases of this kind are important from our point of view, since the enormous volume of water banked up along the coast has eventually to settle down to a uniform level, and this process entails the formation of currents along the path of least resistance which may be completely different from the direction 
of the wind at the time. The currents produced on this occasion must have profoundly modified the course taken by those of our bottles which were in the southern part of the North Sea at the end of November and beginning of December.

\begin{tabular}{|c|c|c|c|c|c|c|}
\hline & January. & February. & March. & April. & May. & June. \\
\hline Plymouth . & $\begin{array}{l}\text { N.E., } \\
\text { moderate. }\end{array}$ & $\begin{array}{l}\text { W.S.W., } \\
\text { strong. }\end{array}$ & $\begin{array}{l}\text { S.W. by W., } \\
\text { very strong. }\end{array}$ & $\begin{array}{c}\text { S., } \\
\text { weak. }\end{array}$ & $\begin{array}{l}\text { N.W., } \\
\text { weak. }\end{array}$ & $\begin{array}{c}\text { W.S.W., } \\
\text { weak. }\end{array}$ \\
\hline \multirow[t]{2}{*}{ British Isles . } & $\begin{array}{c}\text { N.E., } \\
\text { variable. }\end{array}$ & $\begin{array}{l}\text { S. to W., } \\
\text { light gales. }\end{array}$ & $\begin{array}{l}\text { S.W. to W., } \\
\text { stormy. }\end{array}$ & $\begin{array}{c}\text { E.strongest, } \\
\text { variable. }\end{array}$ & $\begin{array}{c}\text { Very } \\
\text { variable. }\end{array}$ & $\begin{array}{c}\text { Very } \\
\text { variable. }\end{array}$ \\
\hline & July. & August. & September. & Oetober. & November. & December. \\
\hline Plymouth . & $\begin{array}{l}\text { W., } \\
\text { weak. }\end{array}$ & $\begin{array}{l}\text { S.W. by S., } \\
\text { very strong. }\end{array}$ & $\begin{array}{c}\text { W., } \\
\text { moderate. }\end{array}$ & $\begin{array}{l}\text { E.S.E., } \\
\text { stiff. }\end{array}$ & $\begin{array}{l}\text { E. by S., } \\
\text { moderate. }\end{array}$ & $\begin{array}{l}\text { S.W., } \\
\text { strong. }\end{array}$ \\
\hline British Isles. & $\begin{array}{l}\text { S.W.toN.W. } \\
\text { variable. }\end{array}$ & $\begin{array}{c}\text { S. to W., } \\
\text { gales in } \\
\text { west, none } \\
\text { in east. }\end{array}$ & $\begin{array}{l}\text { S.W.toN.W. } \\
\text { variable in } \\
\text { south-west. }\end{array}$ & $\begin{array}{c}\text { S.E., } \\
\text { variable in } \\
\text { south-east. }\end{array}$ & $\begin{array}{l}\text { Variable, } \\
\text { great gale } \\
\text { from N.W., } \\
28 \text { th to } 29 \text { th. }\end{array}$ & $\begin{array}{l}\text { S. to W., } \\
\text { some east } \\
\text { on south } \\
\text { coast. }\end{array}$ \\
\hline
\end{tabular}

It will at once be seen that there was a close correspondence in 1897 between the direction of the surface drift in the Channel at different times of the year and that of the winds for the same periods. It is unnecessary to go into details, but I may point out that, in view of this general correspondence, the non-recovery of drift-bottles in January and February is probably to be explained by the marked northerly element in the winds of January. Bottles sent adrift off the Eddystone in this month must have drifted out towards mid-Channel, requiring the strong south-westerly winds which prevailed during the whole of February to bring them ashore at the beginning of March. By a method to be described below, moreover, I have calculated that by the end of February the bottles sent adrift between the 15th and 18th of that month had in all probability been carried north-eastwards into the great bight formed by Lyme Bay, where the conditions as regards wind and tide differ considerably from those prevailing in the fairway of the Channel.

An equally complete analysis of the northward and southward drifts is unnecessary, since the recovery of almost all the bottles on the northern coasts of the Channel speaks for itself. Almost all the drifts, whether to eastward or to westward-but especially in the former case - had a northward element, which carried the bottles to some part or other of the English coast. Two cases of due northward drift are included in the preceding table, one for April, the other for August. In the former case the drift was short and rapid (ten miles in 27 hours, no. XXXII.); in the latter the resultant distance was equally short, but the 
duration was prolonged to 22 days (assuming here, as elsewhere, that the bottle was picked up soon after getting ashore), thus depriving the case of any special significance.

The only period of marked southward drift which is actually indicated by the bottles was in the month of May, when-between the 13 th and the 19th of the month - as many as five bottles, belonging to four February batches, were stranded on the French coast in the neighbourhood of Calais. It is clear also, from evidence supplied by batches XXXVIII. and XL., that similar conditions prevailed at the opposite extremity of the Channel during the same period, which was characterised, as already remarked, by a preponderance of north-westerly winds in the Channel.

The only other month during which northerly winds prevailed was January, and I have already mentioned that the negative evidence supplied by the non-recovery of bottles in February, in spite of strong southerly winds during that month, points clearly to the conclusion that a strong southward drift occurred in January as well.

A temporary southward drift probably occurred also about the middle of June, at any rate in the eastern portion of the Channel, since two bottles, belonging to different batches, stranded at Calais and Boulogne on the 18th and 19th of that month. It is, moreover, difficult to account for the curious data supplied by batch no. XL., except by the assumption that there was a surface current to the southward on the north coast of Cornwall between the middle of June and the middle of August, and again during September. These were periods of variable winds.

\$3. Other Causes of Surface Currents in the Channel.-By the use of the word "drift" in connection with the movements of the surface water which have been described above, I have already indicated that these movements are principally due to the driving power of the wind exerted upon the surface of the water. My employment of the word is amply justified by the close correspondence between the movements of wind and water in the Channel revealed in the preceding section of this report. But it is desirable, before we assume that the local winds have been the only factors concerned in the production of these surface currents, that we should consider for a moment the other causes which may be expected to affect the circulation of the water in the regions under discussion.

In the first place we have to entertain the possibility of a current setting normally through the Channel, independently of the local winds, in connection with the general circulation of Atlantic water. As the Channel is open to the eastward through the Straits of Dover, we might, d̀ priori, expect a continuance through it of the great eastward drift of the North Atlantic. Into the Bay of Biscay this drift 
sets with a velocity varying between 8 and 30 miles a day, while to the north of Scotland, over the Wyville-Thomson ridge, it sets towards the Norwegian coast with a velocity of 5 miles a day. But it has to be borne in mind that the orifice of the Dover Straits is very small and the depth exceedingly shallow, scarcely exceeding 20 fathoms along a line drawn from Dungeness to Boulogne, while the depth of water over the Wyville-Thomson ridge, with which comparison is invited, is 300 fathoms. Moreover, the whole bed of the English Channel scarcely exceeds a depth of 50 fathoms in any part. Friction with the bed of the Channel, combined with the obstacles to further progress presented by the narrowness and shallowness of the Straits of Dover, would appear to be sufficient to prevent the ingress into the English Channel of any serious portion of the general Atlantic drift already retarded by the shallowness of the sea between France and Ireland. That this is actually the case appears from the Admiralty chart of Atlantic surface currents (1875). The bifurcation of the Atlantic drift (the time-honoured Gulf Stream) takes place opposite the entrance to the English Channel, outside a line connecting Ushant with the west of Ireland, thus indicating the serious nature of the obstacle presented by the shallow bed of the Channel; and in this part of the chart the currents are marked as "variable and uncertain."

The improbability of any serious current setting through the Channel as an offset from the general Atlantic drift is in agreement with the results of our experiments. The surface currents in the Channel have been shown to be in general agreement with the direction of the local winds from time to time; and in July, at any rate, there is some direct evidence from our bottles that the water in windless weather is stationary, except for the regular swing imparted to it by the tides. Out of a number of bottles put overboard on the 17th July, during a voyage of the Busy Bee from Falmouth, two, at any rate, were recovered three days later afloat in practically the same spot as that in which they were sent adrift. The weather during this period was almost dead calm, none but the lightest of southerly airs being perceptible. Had any appreciable current, say, of 4 miles a day, been setting up-Channel at the time, the position of the bottles would have been deflected a corresponding amount to the eastwards-12 miles in the example taken. The velocity of the tidal stream at springs in this region is small, from $\frac{1}{2}$ to $\frac{3}{4}$ knot.

At the same time, as the velocity of the Atlantic drift is admittedly dependent on the force of the winds blowing over that ocean, these considerations do not preclude the possible occurrence of eastward currents in the Channel, independently of local winds, after unusually heavy gales to the west of our islands. We shall, I think, be able to 
determine the existence of such occasional currents by applying to the data provided by drift-bottles a method of analysis to be described below.

The possibility of a permanent westward current through the Channel from the North Sea is precluded by the results of Fulton's experiments, which were briefly summarised in Mr. Allen's letter at the commencement of this report.

A second cause of surface currents independent of local winds is to be found in the tides. The tidal stream in the Channel runs with a velocity which in different parts varies from about half a mile to about three miles an hour. There is no need to sum up here the peculiarities of the Channel tides, but as the courses of the flood and ebb streams are approximately parallel over the greater part of the Channel, it does not appear that the course of drift-bottles would be materially affected by them in the long run, except in certain well-defined regions of the Channel. These are principally the two orifices of the Channel, together with Lyme Bay, the neighbourhood of the Solent and Spit Head, and the Gulf of St. Malo.

At the western entrance to the Channel the West Channel tidal stream runs in opposite directions to the oceanic tidal stream, and where the two streams meet the tides are rotary, with scarcely any interval of slack water. Off Mounts Bay the ebb, or west-going stream, runs longer and stronger than the flood, or east-going stream, so that a vessel leaving Mounts Bay at half ebb counts upon a nine hours' tide to carry her up the Bristol Channel. This preponderance of the westward current is due partly to the meeting of the two tidal streams referred to, and partly to the indraught into the Bristol Channel during flood tide. The effect of the tidal currents in this neighbourhood is clearly seen in the case of two of our batches of drift-bottles, nos. XXX. and $\mathrm{XL}$, as will be shown below.

The conditions in the Straits of Dover are similar in principle, though more complicated in detail. Here the West and East Channel streams meet at high water and separate at low water, and there is the phenomenon of an "intermediate tide," which is found running along the shore at high and low water when the main streams are at rest. The Strait of Dover thus never has slack water throughout its extent at any one time, and, as stated in the Channel Pilot, "if a vessel having come up Channel with the last of the West Channel stream running E. enters the intermediate tide running E. off Hastings, she will have a continuation of it for four hours longer, and, if sailing eight knots, will carry it to the N. Foreland."

On the other hand, at the commencement of flood in the southern portion of the Straits, owing to a simultaneous set of the intermediate 
tide to the south-westward and of the West Channel stream to the south-eastward, there is a strong convergence towards the French coast between Dieppe and Boulogne. I have not, however, examined minutely the effects of the Dover tides upon any of our drift-bottles on the present occasion. The general occurrence of a southerly component in the Channel winds renders it probable that most of our bottles entered the Straits on the English side, where the net resultant of the tidal influences appears to be in the same direction as the prevalent winds, whose drift they would merely reinforce. In the case of Mounts Bay, as already pointed out, the stronger currents are in the opposite direction.

The influence of the tidal indraught towards Boulogne possibly accounts for the fact that the only bottles recovered on the French coast west of Calais were found at Le Portel, near Boulogne-one on June 19th, the other on August 5th (batches XX. and XXII.).

The strong tidal currents at the entrances to the Gulf of St. Malo may have to be considered in future reports; but as only one batch of our bottles approached this region last year, it does not appear to be profitable to discuss their course on the present occasion.

In Lyme Bay, however, partly owing to the conformation of the coast line, and partly to the indraught of the great tides in the Gulf of St. Malo, the tidal currents are very weak, and, instead of a parallel ebb and flow in the northern part of the bay, the tidal stream in this position is rotary in direction, changing, with the hands of a clock, "round the compass, with little or no velocity." The slight velocity of this vortex, compared with that due to wind-action, enables us to neglect its effects upon the surface drift under ordinary circumstances. But on the eastern side of the bay a stream runs to the south-eastwards for nine hours out of the twelve, after apparently making the circuit of the bay from the Start to Portland. Off Portland Bill the well-known "Race" is due to a combination of this outset from the bay, which has gradually increased in velocity along its course, and a counter-stream from East Portland Bay which sets for $9 \frac{1}{2}$ hours. In N. winds the race extends nearly two miles from the Bill, with great overfalls beyond that distance; but with S. winds it scarcely exceeds half a mile. The velocity of the race at springs is six or seven knots.

It is clear that drift-bottles in the eastern part of Lyme Bay will tend to the southward, independently of the winds, as a direct result of the tidal currents here. In the western part of the bay they are not only protected from the direct action of westerly and south-westerly winds, but as a result of the slow tidal vortex tend to be carried northwards and then eastwards with the stream which sets to Portland. It is a remarkable fact that only two of our bottles were recovered 
on the shores of Lyme Bay: one on August 22nd on Chisel Beach, the other on August 30th at Charmouth, near Lyme Regis. Yet there is every reason to believe, as will be shown below, that most of the February bottles were in the western part of Lyme Bay at the end of that month. We are conducting a special series of experiments in this region during the current year.

It appears accordingly, as a result of the above considerations, that the general eastward drift of the Atlantic is probably not continued through the English Channel as a current independently of the local winds; and that the deflecting influence of the tides upon the surface drift is immaterial in the fairway of the Channel, but may be considerable in certain well-defined regions of the Channel in proximity to the shore.

The motion of the surface currents in the Channel will therefore depend principally on the force and direction of the local winds, but will be subject to modification by tidal currents in the regions enumerated.

$\S$ 4. The Law of Drift.-When discussing the influence of the local winds upon the course of our bottles in $\S 1$ the matter of direction was alone considered, questions of velocity being entirely neglected.

But as the exact route taken by the bottles is of considerable importance, it is desirable that some attempt should be made to determine the ratio between the velocity (or force) of the winds and the velocity of the surface currents set up by their action, even though we can only hope to attain a limited degree of accuracy.

The only investigation upon this point with which $I$ am acquainted is contained in Mohn's classical memoir on the circulation of the North Ocean, published in the Reports of the Norwegian North Atlantic Expedition (1887, pp. 117-123). According to Mohn, a wind of force 3.9 on the Beaufort scale produces a drift having a velocity of 15 nautical miles per diem. Converting the force of the wind to its velocity according to Scott's table, he gets:

$$
\begin{gathered}
\text { Wind force } 3.9=\text { wind velocity } 22.5 \text { miles per hour }=\text { drift } \\
\text { velocity } 15 \text { miles per diem. }
\end{gathered}
$$

This result was gained by computing the mean velocities of the equatorial current and of the trade winds from a large number of cases in which the mean directions of the current and wind approximately coincided. The resultants of the two sets of calculations were then regarded as respectively equivalent.

The velocity of the drift in this and subsequent cases considered by Mohn was taken to be directly proportional to the velocity of the wind.

It seems to me to be clear from this account that Mohn's drift equivalent is only applicable to cases of permanent currents. In his datum 
case a wind of force 3.9 was not shown to be capable of producing a current of velocity 15 miles per diem from rest; it is merely the force of wind sufficient to maintain such a current when already in motion with that velocity. It provides a datum for estimating the mean velocity of a permanent drift when the velocities of the winds in the same region are known, or conversely. But it does not establish a means of determining the effect of the wind upon the sea in a region not subject to a regular circulation, such as the English Channel, if I am right in my attitude upon this point. The currents in the Channel have to be raised practically from rest, since the great variability of the winds prevents the formation of currents with any such momentum as that of the permanent currents.

As, however, the wind frequently blows from the same quarter for several days in succession, its effect upon the water will be relatively greater under these circumstances than when blowing intermittently. The momentum of the drift produced by high winds will be considerably greater than for low winds, and the waves raised by strong winds will enable these winds to exert a propelling force upon the water, in addition to the normal dragging force. All these circumstances seem to me to show that the velocity of a current raised in a given time will be relatively very much greater when raised by a high wind than by a low wind. Without therefore attempting to treat the matter from the difficult point of view of hydrodynamics, it nevertheless seems justifiable to regard the velocity of the current as approximately proportional to the pressure rather than to the velocity of the wind, the pressure being a constant fraction of the square of the velocity.

§5. Empirical Datum.-On examining the results of the year's experiments one case of drift stood out clearly from the remainder as supplying a datum, comparatively free from sources of error, in regard to the measurable effect of the wind in producing a surface drift, viz., batch no. XXXIX. Out of five bottles put out near the Eddystone on April 22nd one was recovered exactly three days later (73 hours) at Portscatho, situated 25 miles to the westward. The wind during this period was remarkably uniform in force and direction from the eastward, owing to an area of high pressure lying to the N.E. of our islands; and the duration of drift was sufficiently long to allow the oscillating effect of the tides to be discounted. The winds during April, moreover, were very variable, so that we may assume this particular drift to have been raised from rest, especially as on the day preceding that on which the batch was put out a calm prevailed in this portion of the Channel. This assumption is confirmed by the fact that a bottle of batch XXXVII., put out in the same place on the preceding day (April 
21st), was recovered at Portscatho also on the 25th. The two bottles were recovered by different individuals at different times of the day. We may assume, therefore, that they had not lain long on the shore before being picked up.

The force of the wind was taken to be the mean of the forces recorded at Prawle Point, Plymouth, and Falmouth. The records for Prawle Point and Plymouth are expressed in terms of the Beaufort scale, the former being extracted from the Daily Weather Reports of the Meteorological Office, and the latter being supplied to me by the Borough Meteorologist at Plymouth. The Falmouth records are the readings of the automatic anemograph at the Falmouth Observatory, and are expressed in units of velocity (miles per hour). To compare these records I have employed Scott's table of the velocity-equivalents of the various figures of the Beaufort scale. The recorded direction of the wind during the period was approximately the same at all three stations, i.e., about E.N.E., but the records of the force of the wind showed more discrepancy than might have been expected. At Prawle Point the force varied between 5 and 7 throughout the period, the average being 6 ; at Plymouth it was more variable, and the average was 4 ; while at Falmouth the resultant average velocity compiled from the 73 hourly records during the period only amounted to 13.9 miles per hour, which is equivalent to a force intermediate between 2 and 3 on the Beaufort scale, but much nearer 2 than 3 . It is reasonable to expect that the force of an E.N.E. wind blowing over the southern part of our islands should be weaker at Plymouth than at Prawle Point, owing to the retarding effects of greater friction, for such a wind at Prawle Point would come to an observer there direct from the sea (Lyme Bay), while at Plymouth it would be distinctly a land breeze. But it is difficult to understand the low readings of the anemograph at Falmouth during this period, especially as there was no corresponding reduction in the force of the wind further westward, the force at Scilly being recorded in the Daily Weather Reports as varying between 4 and 6 , the average being 5. The error introduced by the employment of a table of velocityequivalents of the Beaufort forces no doubt partly accounts for the lack of correspondence between the data, and the records at Prawle Point were possibly in this case slightly in excess of the actual velocities; but there is still a residuum of error which must apparently be attributed to the effects of local environment upon the velocity of the wind recorded at the Falmouth Observatory.

However, by taking the mean of the observations at Prawle, Plymouth, and Falmouth we shall probably eliminate the errors of observation and measurement, and obtain a fairly true measure of the force of the winds over the sea in this district for the period in question. The resultant 
winds were calculated independently in each case in terms of pressure, by constructing a polygon of forces from each set of data, the length of each line being made proportional to the sum of the wind pressures from the corresponding quarter. The records on the Beaufort scale and those in terms of velocity were reduced to terms of pressure by means of the following table* of equivalents :-

$\begin{array}{llllllllllllllll}\text { Force, Beaufort seale } & \text { - } & & 0 & 1 & 2 & 3 & 4 & 5 & 6 & 7 & 8 & 9 & 10 & 11 & 12\end{array}$ $\begin{array}{lllllllllllllll}V \text { elocity, miles per hour } & \text { - } & 3 & 8 & 13 & 18 & 23 & 28 & 34 & 40 & 48 & 56 & 65 & 75 & 90\end{array}$

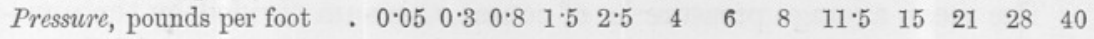

This method is founded on that employed by Dr. Fulton $\dagger$ in his report on the drift-bottle experiments of the Scottish Fishery Board, but differs, for reasons already stated, in the employment of terms of pressure instead of terms of "force" for the construction of the polygon. The practical result of this change is easily seen from the following examples: -On Fulton's method a wind of force 9 is regarded as only 3 times as effective (in the production of currents) as a wind of force 3 ; by using terms of pressure, however, the same wind is regarded as 10 times as effective $\left(\frac{15}{1 \cdot 5}=10\right)$. Similarly on Fulton's method a wind of force 8 is only twice as effective as one of force 4 ; on mine it is regarded as between 4 and 5 times as effective $\left(\frac{11 \cdot 5}{2 \cdot 5}=4 \cdot 6\right)$.

In the case of the Prawle winds the observations taken daily at 8 a.m. and 6 p.m. were used, for Plymouth those at 9 a.m. and 9 p.m., while at Falmouth the hourly records were used, amounting to 73 in all for this period of drift. As the bottle was put overboard at 3 p.m. on April 22nd, and recovered at 4 p.m. on the 25th, half the wind-pressure on the evening of the $22 \mathrm{nd}$ was combined with half the pressure on the morning of the 25th in the Prawle and Plymouth cases. The results, as determined by the length of the resultant line in the polygons, was as follows:-

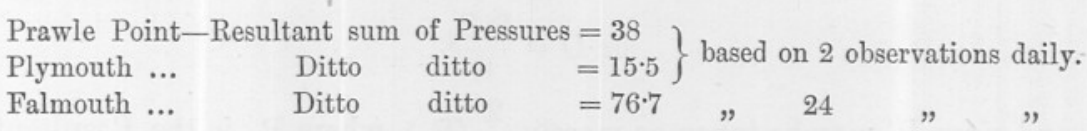

Dividing the Falmouth resultant by 12, in order to put it on a par

* This is the table authorised by the Meteorological Office in 1875 after the publication of Scott's paper, with the addition of a table of pressure-equivalents. The latter are computed from the velocities by multiplying the squares of the velocities by the factor 0.005 , and expressing the results as far as possible in whole numbers. A more recent table of velocity-equivalents by Mr. Curtis (Quart. Jour. Met. Soc., XXIII., 1897), has been kindly forwarded to me by Mr. Scott, but reached me too late for use in the present report. It differs from Mr. Scott's table in assigning somewhat lower velocities to all the figures of the Beaufort scale.

† Fifteenth Annual Report of the S.F.B., Part III., 1897, p. 357. 
with the other figures based only upon two observations daily, we get the mean of these three resultants as follows :-

$$
\text { Mean }=\frac{38+15 \cdot 5+6 \cdot 3}{3}=\frac{59 \cdot 8}{3}=19 \cdot 9 \text {, or, practically } 20,
$$

which is the measure in pounds per foot of the resultant of the windpressures, taken twice daily, during the period of drift.

The mean average pressure is, of course, this sum divided by the number of days and the number of observations per diem, or $\frac{20}{3 \times 2}=3 \cdot 3$, which is equivalent to a velocity of 26 miles per hour, or a "force" intermediate between 4 and $5(4 \cdot 6)$ on the Beaufort scale.

The resultant or minimum distance traversed by the drift-bottle from the Eddystone to Portscatho $=25$ geographical miles.

We conclude therefore that a wind exerting a horizontal pressure of $3 \cdot 3$ pounds per foot ( $=$ a velocity of 26 miles per hour, or a force intermediate between 4 and 5), and blowing steadily for three days, will cause a surface drift in the same direction of 25 miles in that time, i.e., a current having a surface velocity of 8.3 miles per diem.

This result is considerably lower than that attained by Mohn, and bears out my remarks concerning the inapplicability of Mohn's currentequivalent to cases of currents produced by the wind from rest.

Having thus determined the drift-equivalent, it is easy to construct a factor from it by which the resultant wind pressure for any period may be quickly converted into the number of miles travelled by the surface drift for the same period.

If $\mathrm{D}$ be the Distance travelled in miles, and $\mathrm{P}_{2}$ the resultant WindPressure in pounds per foot computed from 2 observations daily,

$$
\begin{gathered}
\text { then } \mathrm{D}: \mathrm{P}_{2}:: 25: 20, \\
\text { or } \mathrm{D}=\frac{5 \mathrm{P}_{2}}{4} ;
\end{gathered}
$$

and since $\mathrm{P}_{2}$ may be taken as merely $\frac{2}{n}\left(\mathrm{P}_{n}\right)$, where $\mathrm{P}_{n}$ is the Resultant Pressure determined from $n$ observations daily, we have the general formula

$$
\mathrm{D}=\frac{5 \mathrm{P}_{2}}{4}=\frac{5\left(\frac{2}{n} \mathrm{P}_{n}\right)}{4}=\frac{5 \times 2 \mathrm{P}_{n}}{4 \times n}=\frac{5 \mathrm{P}_{n}}{2 n} .
$$

In most cases it is, of course, sufficient to determine the resultant wind and wind pressure for any period from the observations recorded twice 
daily at different stations, and the factor then becomes simply $\frac{5}{4}$; or $\mathrm{D}=\frac{5 \times \text { Resultant Pressure }}{4}$, which gives us the number of miles drifted.

The accuracy of this equivalent can only be determined by the frequency with which its results accord with those of direct experiment. It depends on an assumption which may invite criticism, viz., that the velocity of the drift varies as the pressure of the wind, and not directly as its velocity. This pressure-ratio is confessedly only an approximation to the true law of drift, but I consider it to be nearer the truth than the velocity-ratio adopted by Mohn, which assumes the existence of a level sea for winds of all velocities.

§. Application of Factor to cases of Drift.-The use of drift-bottles for estimating the velocity of drift is attended by a possible source of serious error, viz., the difficulty of determining the length of time between the actual stranding of a bottle and its subsequent recovery. In some cases this source of error is removed by the statements made by the finders of the bottles, but in most cases it must always remain as a condition to be taken into account. On the whole, however, I believe that the maximum error due to this cause is inconsiderable except when the bottles have been recovered in unfrequented parts of the coast. Most bottles are picked up in the neighbourhood of towns and fishing ports where the shore is much frequented, and in other regions the coastguardsmen are always on the look-out. The conspicuousness of our bottles must also tend to reduce the error due to this cause. Altogether I should estimate the average error as amounting to not more than 12 hours in summer and 24 hours in winter, which is inconsiderable except for short journeys. I would particularly point to the records of batches LII. and LIII. in support of these remarks. The simultaneity with which so many of these bottles were recovered by different individuals after drifting for more than a fortnight is well worthy of note, and we have had still more striking examples of the same thing this year.

The following table shows the results of an application of the driftfactor to certain cases of drift recorded in Table I. Open water and an absence of deflecting currents are assumed. The actual direction and distance of drift are compared side by side with the estimated direction and distance of drift, and these have been calculated from the winds prevailing at the time by the employment of the factor and the method already described. The wind records, except those of Rousdon and Falmouth, were extracted from the Daily Weather Reports of the Meteorological Office. 
Table comparing the Estimated and Actual Drift for various periods.

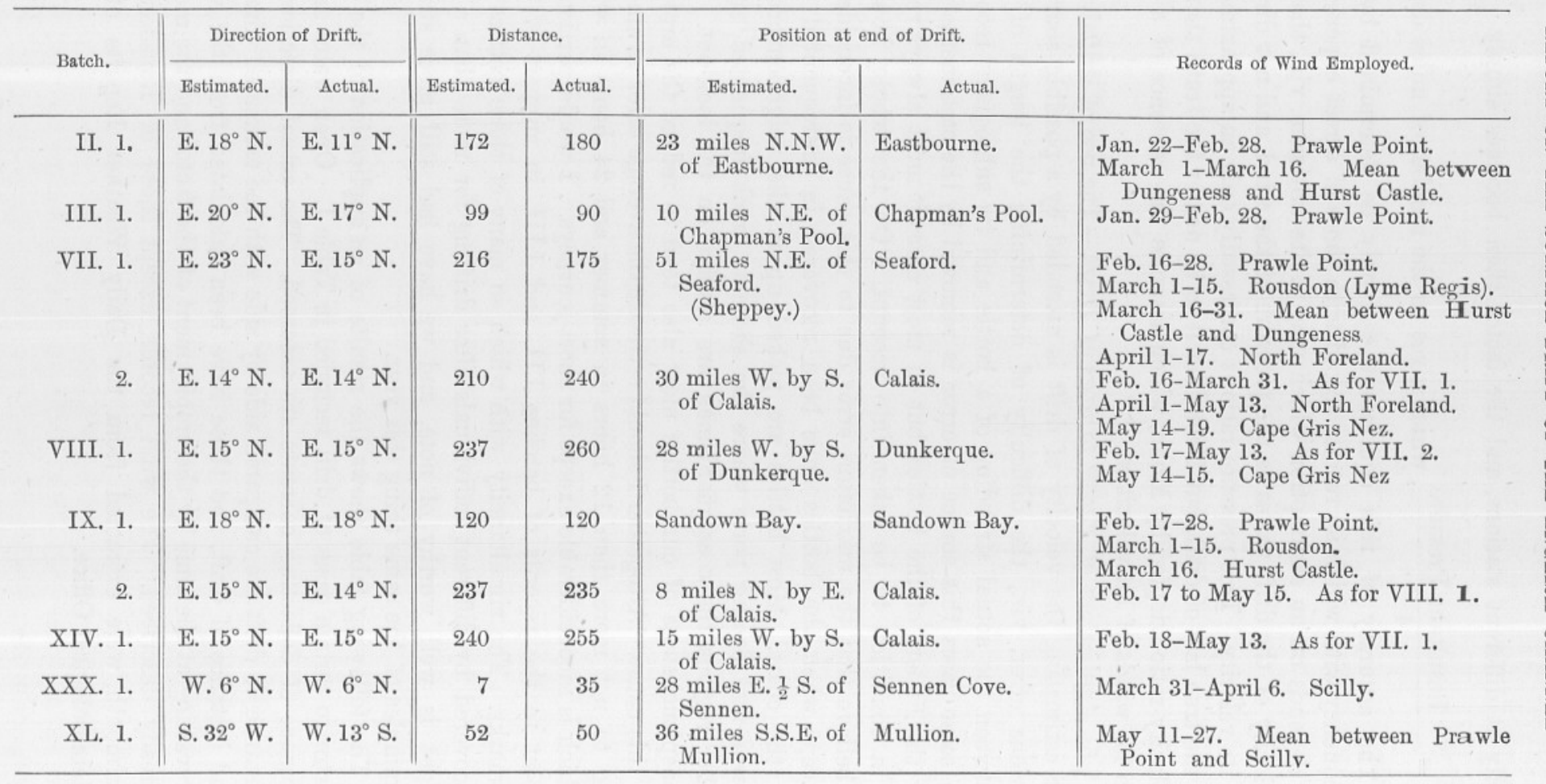


It is seen from the preceding table that in only one out of ten cases of drift does my calculated drift exactly coincide with the records of the bottles (IX. 1); but in several other cases the results correspond in a sufficiently close manner for all practical purposes. Some further examination, however, is necessary before the reliability of my method can be depended upon, because the estimated results depend upon the assumption of open water, and this cannot always be conceded.

In the case of II. 1 there is an angular error of $7^{\circ}$ in a course of 180 miles, the estimated and actual distance of drift being practically identical. In this instance there can be no question of any deflection of the drift by the proximity of the shore. My calculations from the winds at Prawle Point, from January 22nd to January 28th, give an estimated drift of 34 miles in a $\mathrm{S}$. by $\mathrm{E}$. direction, which would thus convey the bottles well into mid-Channel. The Prawle winds for the ensuing period, January 29th to February 28th, give an estimated drift of 99 miles in an E.N.E. direction, bringing the bottles to a position about 26 miles S. by W. of the Needles. The direction of the drift during March 1st to 16 th was estimated as N.E. $\frac{1}{2}$ E. in this part of the Channel. The direction of the strong winds immediately before the recovery of the bottle was as follows:-March 16th, S. to S.S.W.; March 15th, S.S.W.; March 14th, S. to S.S.E. Clearly the bottle was not driven to Eastbourne from the westward side of Beachy Head by a current parallel with the shore, but must have been almost due S., or even S.S.E., of Eastbourne when overtaken by the gale, as the recovery of another bottle to the eastward a few days later also shows. The error iu my estimate is not due therefore to shore-deflection, but to an excess in the southerly component of the wind records employed This is just what one would expect under the circumstances, since the records employed were those of Prawle Point, Hurst Castle, and Dungeness. All of these stations are situated on the northern coast of the Channel, and are consequently more exposed to the full force of southerly than of northerly breezes. The course of the bottles, however, was in mid-Channel for a considerable distance, and thus equally subject to the influence of winds from north and south. That this is the true explanation is seen from the fact that while the resultant wind for March 1st to 16 th was S.W. $\frac{3}{4}$ S. at Hurst Castle, and S.W. $\frac{1}{3}$ W. at Dungeness, it was nearly W.S.W. at Jersey (S.W. by W. $\frac{1}{2}$ W.), the force at the three stations being approximately the same. The error could have been avoided by taking the mean between these three winds for the period; but I have preserved my estimate in its original form in order to show by an example the precautions in this respect which must be taken when very accurate results are desired.

In the second case (III. 1) we have again an angular error to the NEW SERIES, - VOL, v. No. 2. 
northward, but of small value $\left(3^{\circ}\right)$. The disturbing effects of Portland Race perhaps account for this slight discrepancy; but a closer estimate would probably have been obtained by taking the mean between the Prawle Point and Rousdon winds. During March, when the state of the wind was very similar to that in February, I found that the records at Rousdon indicated a stronger component from the northward than did those at Prawle Point.

The six succeeding cases deal with batches all of which were represented in the neighbourhood of Calais by bottles recovered between the 13th and 19th May. They are, therefore, of particular interest as throwing light on the whole course of drift. There is a glaring discrepancy between the estimated and actual drift of the Seaford bottle (VII. 1); but the remainder conform moderately well, especially when the length of the journeys involved is taken into account. From the close correspondence between estimated and actual drift in cases IX. 1 and 2 we may, I think, conclude that the inferences to be drawn from the use of the drift-factor in all these cases are reliable. In the Seaford case there is an angular error of $8^{\circ}$, a distance error of 41 miles, and a serious geographical discrepancy of position. Had there been open water in the estimated direction of drift, the Seaford bottle should have been on the east coast of Sheppey on April 17th. We see, however, from IX. 1 that these bottles, which from their eventual destination we may shortly term the Calais bottles, were off the south coast of the Isle of Wight about March 16th, and so violent were the westerly gales of the latter half of March that the estimated drift during that period was 120 miles in a N.E. by E. direction, which would bring the bottles to a position 5 or 6 miles E.N.E. of the Nore Lightship off the mouth of the Thames. The Sussex coast, however, would interpose an impassable barrier to such a course, and two alternatives would present themselves: (1) the bottles must drive at once ashore, or (2) the bottles must be deflected from their estimated course by a current racing eastwards along the shore towards the Straits of Dover. The latter course appears to have been taken in most cases, and the bottles were probably in the lower part of the North Sea, between the Essex and Belgian coasts, at the end of the month. That the passage of the Straits was made at this time in spite of the southerly component in the winds is rendered all the more probable because a bottle of batch II., which was off the coast of Eastbourne on March 16th, was recovered at Terschelling on March 30th. This is equivalent to a distance of 250 miles in 14 days, or almost 18 miles a day. Now the estimated drift, directly dependent on the pressure of the wind during this period, was 120 , or at most 140 miles. This velocity was therefore nearly doubled, no doubt partly owing to the head of water accumulated in the eastern part of the Channel 
during the gales, and partly to the narrowing of the Channel in this region. This result accords with the experience of navigators, for, according to the Pilot's Handbook (12th ed., 1893, p. 142), "strong W. gales prolong the intermediate stream running E., and retard the stream running S.W. At such times the streams at the Ridge shoal have been found to run 8 hours to the N.E., and only 4 hours to the S.W."

But there is no reason to assign to any of the Calais bottles the remarkable velocity attained by this Eastbourne-Terschelling bottle (II. 3) during the latter half of March. The latter bottle would begin to experience the acceleration caused by the narrowing of the English Channel almost immediately after the commencement of the westerly gales in mid-March, as Beachy Head marks the western boundary of the funnel-shaped extremity of the Channel; but the Calais bottles at this time (March 16th) were 50 miles to the westward, off the east coast of the Isle of Wight, in one of the widest parts of the Channel. During the third week of March, therefore, although the direction of drift of the Calais bottles would be deflected to a course parallel with the coast, their velocity would scarcely differ from that directly due to the pressure of the wind, which we have already seen was calculated to be 120 miles for the fortnight, or 60 miles for the week, which would bring them slightly to the eastward of Beachy Head. From this point they would begin to experience an accelerated velocity; and, if we assume that they travelled at the same average rate as the EastbourneTerschelling bottle (18 miles a day), their position at the end of March would be 125 miles to the north-eastward of Eastbourne, or somewhere in a line between Harwich and the Hook of Holland, and probably on the westward side of the middle of this line. Such a position would be about 60 miles N.N.E. or N. by E. of Calais. Now the estimated direction of drift in this region from April 1st to 30th, based on the North Foreland winds, was W. $\frac{1}{2}$ S., 29 miles, which would bring the bottles to a position slightly south of Harwich, off the Naze, by the end of that month. The Naze is rather under 60 miles N.N.W. of Calais. The estimated drift from May 1st to 13th, based on N. Foreland winds, was approximately E.S.E. (actually S.E. by E. $\frac{7}{8}$ E.), 56 miles; or, based on the winds of Cape Gris Nez, S.E. $\frac{1}{8}$ S., 59 miles; so that, obeying this drift, the bottles on May 13th would be within a mile or two of the French coast between Calais and Dunkerque, a result which coincides remarkably with the actual position of the bottles about that time, and demonstrates the general accuracy of the method employed in this report for deducing the course of drift from the direction and pressure of the winds.

Apart from the employment of this quantitative method, a mere survey of the records contained in the table showing the recovery 
of drift-bottles would have led one to the conclusion that the eastward drift of these bottles was a more or less steady and continuous one from March 16th, when they were off the Isle of Wight, until the middle of May, when they were stranded on the French coast. The recovery of a bottle at Seaford in April points clearly to such a conclusion, and the direction of the resultant winds at Dungeness during the latter half of April (E.N.E., light) and the first half of May (W. by N., moderately strong) appeared to me at first sight to accord with the view that all the Calais bottles were in the neighbourhood of Seaford in mid-April. It was not until I made the extensive calculations required for the above analysis that I finally convinced myself of the serious error of this view, and of the certainty that the Calais bottles had already made the passage of the Dover Straits in the last week of March, owing to the production of a current along the coast of Sussex at an angle with the direction of the wind during the last fortnight of March.

In order to explain the case of the Seaford bottle we must go back to the position of the Calais bottles prior to the southerly gale of March 16th, which drove so many ashore. On March 16th and 17th several bottles were stranded on the S.E. coast of the Isle of Wight by this gale, but one, at least (XI. 1), was stranded about the same time on the S.W. coast of the same island, and another was recovered in the Solent on March 31st (XIII. 1.). Now this latter batch did not arrive at Calais until June 18th. It is probable, therefore, that the cause of retardation in this case was that these bottles had not easted sufficiently by the 15th March to be able to round St. Catherine's Point when the southerly gale of the 16 th overtook them. Those which were to the eastward of the Point, and escaped stranding, were driven rapidly along the Sussex shore to the Straits of Dover; but those which were to the westward of the Point were either driven ashore on the west coast of the island or into the Solent. Their course through the Solent and Spithead to the eastward would be distinctly slow, as they would lose a considerable portion of the direct effect of the westerly gales; and I imagine that the Seaford bottle may have been retarded in this way, while others of the same batch succeeded in clearing St. Catherine's Point, and pursuing an unobstructed course. A difference of a few miles between the positions of bottles on the 15th of March would be sufficient to determine whether they would be carried to the eastward or westward of St. Catherine's Point. If the Seaford bottle actually took the course here suggested it must have slowly drifted eastwards through the Solent and Spithead, and emerged off Selsea Bill during the last few days of March, pursuing a course along the Sussex coast under the influence of the westerly winds. The resultant westerly wind of April 1st to 17th was estimated from the winds at Dungeness 
to produce a drift of 24 miles in an E.N.E. direction (actually N.E. by E. $\frac{1}{2}$ E.). The distance of Seaford from Selsea Bill is 34 miles. This suggestion as to the course of the Seaford bottle, therefore, is sufficiently consistent with the conditions prevailing at the time, and with the remainder of our records, to render it the probable explanation of the conspicuous lack of correspondence between actual and estimated drift in this case. Another alternative is that the bottle may have been driven ashore between the 16th and 19th March on the east coast of the Isle of Wight, or on the Sussex shore west of Selsea Bill, as occurred in the case of III. 4, and that it remained ashore until the latter end of March, when it resumed its eastward drift ; but I consider this theory much less probable. What I hold to have established is that the course of the Seaford bottle was quite exceptional, and that its position on the 17 th April does not indicate the position of the remaining bottles of the same batch on that date; for there was a general tendency for bottles put out near the Eddystone between the 16th and 18th of February to arrive on the French coast between Calais and Dunkerque between the 13th and 19th May, and I have shown that this could be achieved, provided the bottles passed through the Straits of Dover in the last week of March. It was, on the other hand, impossible, if the bottles were in the neighbourhood of Seaford in mid-April. The distance from Seaford to Calais is 70 miles, the direction E. $12^{\circ} \mathrm{N}$.; but the estimated drift for the period April 17th to May 13th (based on the winds at Dungeness) is only 35 miles, and the direction E. $30^{\circ} \mathrm{S}$., an error both of direction and distance which is too serious to be due to the method of computation, and which admits of no explanation from the nature of the winds prevailing at the time.

The two last cases in the table now require consideration. The first of these (XXX. 1) is the drift of two bottles from the Manacles to Sennen Cove, a distance of 35 miles, during the first week of April. The fact that two bottles pursued the same course shows that the causes of the drift were very constant. The case is the more remarkable as two headlands - the Lizard and the Land's End-had to be rounded during the drift. Now my estimated drift for this period, though in the right direction, is remarkably deficient in distance. Indeed, so variable were the winds in this part of the Channel during this period that it is quite impossible to attribute the drift in this case to the action of the wind. As a check upon my estimate based on the Scilly records, I have also made a calculation as to the direction and distance of drift based on the winds at Falmouth, using the complete set of hourly records of the anemograph for the period. The result is equally inadequate. I have also estimated the drift on the assumption that the rate of drift is proportional to the velocity of the wind, which only made matters worse, 
since it yielded an estimated drift of only 3 miles in a direction W. $24^{\circ}$ $\mathrm{N}$. It is obvious that in this case the rapidity of the drift round the Cornish headlands was due to some cause other than the winds, and, as already described in an earlier section of this report, the known peculiarities of the tidal streams in this region provide an adequate explanation. The indraught into the Bristol Channel during the flood-tide here causes a marked set to the northward round the Land's End, and this brings about a predominance of the westward tide over the eastward tide in this part of the English Channel. In fact, the English Channel supplies more water to the Bristol Channel during flood-tide than returns to it on the ebb from the same region.

The last case of all (XL. 1) appears to illustrate the same point. There is an angular error of $45^{\circ}$ in my calculated drift, but the estimated distance is approximately correct. The deflecting cause may be regarded as equivalent to a current in a N.N.W. direction having an average velocity of 36 miles in 16 days, i.e., rather over 2 miles per diem. There seems to be no reason for doubting that this deflection was due to the influence of the resultant northward tendency of the tides in the western region of the Channel, which is determined by the indraught into the Bristol Channel during flood-tide in that region. We have seen in the preceding case (XXX. 1) that the force of this indraught determines a current round the Lizard and Land's End of some 30 miles in 6 days, i.e., 5 miles a day; so that, although this deflecting influence was not fully felt during the whole period of drift in the present case, we are probably correct in attributing the observed deviation to the same cause, since the south-westward drift caused by the winds would bring the bottles nearer to the influence of the indraught on each successive day; and, in order to complete the distance between the eventual estimated and actual positions, it would suffice if the full influence of the indraught ( 5 miles per diem) were only felt during the last seven days of drift.

$\S 7$. Conclusions.-Enough has been said, I think, to show that the method employed here for tracing the actual influence of the winds on the water is sufficiently accurate for practical purposes, and that by its employment, with proper precautions, the influence of the winds may be separated from that of other factors which operate in the production of surface currents. From this point of view the method may be of considerable use in the future for determining the existence of currents not produced by local windaction. At the same time the method requires to be tested extensively before it can be used as a basis for conclusions. The present report pretends only to show that the relation between wind-action and surface currents is capable of quantitative study, and that the results 
obtained by the use of the methods here described are sufficiently accurate to encourage the further use of them. This we are doing during the present year on a larger scale, and the results will be set out in next year's report. It is very desirable that experiments should be made to determine the depth of the currents induced by wind-action, and we propose to attempt this work during the present year. A comparison of results obtained by bottles floating at the surface, and by other objects designed to come under the influence of lower strata of water, should yield results of considerable value. Until such experiments are made, however, it does not appear to be desirable to say too much upon the practical aspects of the experiments described in this report. We have obtained a general view of the movements of the uppermost layer of water, and we may be certain that similar, though slower, movements also affect the layers immediately subjacent; but the actual depth to which this movement would be communicated under different conditions of wind and tide is a matter of too much practical importance to be left to mere guesswork. As Mohn has well said: "Neither argument nor estimate, but carefully worked-out computations alone, can lead to a lasting result."

\section{St. George's Channel and Irish Sea.}

Owing to the fact that our experiments in this area only cover the summer and autumn months, it does not appear to be advisable to make any attempt to generalise the results obtained, the data given in Table II. being self-explanatory. I may remark, however, that in all the cases which I have specially analysed, the actual drift differs from the estimated drift in taking a more northward direction. This result appears to agree with that obtained by Professor Herdman in his experiments in the Irish Sea. (Proc. Liverpool Biol. Soc., vol. x.).

Nоте.-In the tables which follow, as well as in the preceding portion of this report, the positions of places and directions of currents are invariably indicated by their true geographical bearings, and not by their compass (magnetic) bearings. As the directions of winds are uniformly indicated in true geographical terms, and as compass bearings differ with latitude and longitude, it seemed desirable to use true geographical bearings throughout this report, in order to avoid the possibility of confusion. 
TABLE I.-ENGLISH CHANNEL AND NORTH SEA.

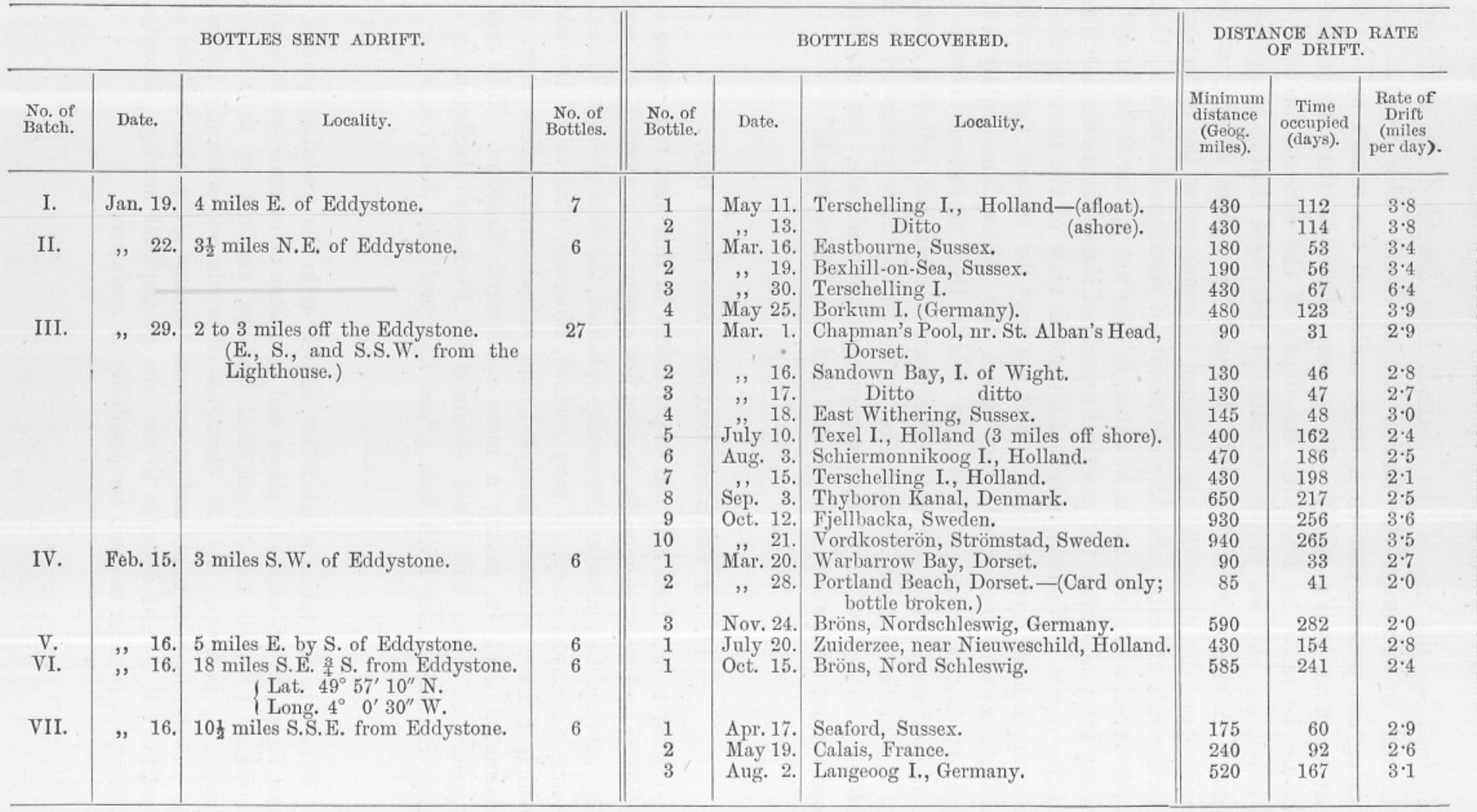




\begin{tabular}{|c|c|c|c|c|c|c|c|c|c|}
\hline $\begin{array}{l}\text { VII. } \\
\text { VIII. }\end{array}$ & $\begin{array}{c}\text { Feb. } 16 . \\
,, 17 .\end{array}$ & $\begin{array}{l}10 \frac{1}{2} \text { miles S.S.E. from Eddystone. } \\
11 \text { miles S.S.E. } \frac{1}{2} \text { S. from Eddystone. }\end{array}$ & 6 & $\begin{array}{l}4 \\
1 \\
2 \\
3\end{array}$ & $\begin{array}{r}\text { Aug. } 15 . \\
\text { May } 15 . \\
\text { June } 27 .\end{array}$ & $\begin{array}{l}1 \text { mile S.E. of Heligoland. } \\
\text { Dunkerque, France. } \\
\text { Baraques, near Calais. } \\
\text { North Sea, } 26 \text { miles N.W. by N. from } \\
\text { the Hook of Holland-(afloat). }\end{array}$ & $\begin{array}{l}540 \\
260 \\
240 \\
345\end{array}$ & $\begin{array}{r}180 \\
87 \\
91 \\
130\end{array}$ & $\begin{array}{l}3 \cdot 0 \\
2 \cdot 9 \\
2 \cdot 6 \\
2 \cdot 6\end{array}$ \\
\hline IX. & " 17. & $\begin{array}{l}11 \text { miles S. by W. from Bolt Tail, } \\
\text { S. Devon. }\end{array}$ & 6 & $\begin{array}{l}4 \\
1 \\
2\end{array}$ & $\begin{array}{l}\text { July } 31 . \\
\text { Mar. } 17 . \\
\text { May } 19 .\end{array}$ & $\begin{array}{l}\text { Amiland I., Holland. } \\
\text { Sandown Bay, I. of Wight. } \\
\text { Calais. }\end{array}$ & $\begin{array}{l}450 \\
120 \\
235\end{array}$ & $\begin{array}{r}164 \\
28 \\
91\end{array}$ & $\begin{array}{l}2 \cdot 7 \\
4 \cdot 2 \\
2 \cdot 5\end{array}$ \\
\hline $\mathrm{X}$. &,, 17. & $\begin{array}{l}10 \text { miles S.S.W. of Bolt Tail ( } 2 \text { miles } \\
\text { to N.W. of IX.). }\end{array}$ & 6 & $\begin{array}{l}1 \\
2\end{array}$ & $\begin{array}{l}\text { Feb. } 18 . \\
\text { Mar. } 3 .\end{array}$ & $\begin{array}{l}\text { E. end of Plymouth Breakwater. } \\
\text { Laira, Plymouth. }\end{array}$ & $\begin{array}{l}15 \\
18\end{array}$ & $24 \mathrm{~h}$. & $\begin{array}{r}15 \cdot 0 \\
1 \cdot 2\end{array}$ \\
\hline $\mathrm{XI}$. & , 17. & 11 miles S.S. E. from Dodman Point, & 6 & $\tilde{1}$ & Mar. 18. & Brighstone Bay, I. of Wight. & 135 & 29 & $4 \cdot 6$ \\
\hline $\begin{array}{l}\text { XII. } \\
\text { XIII. }\end{array}$ & $\begin{array}{ll}, & 18 . \\
, & 18 .\end{array}$ & $\begin{array}{l}5 \text { miles S.S.W. from Eddystone. } \\
17 \text { miles S.S. W. } \frac{1}{2} \text { S. from Eddystone. }\end{array}$ & $\begin{array}{l}6 \\
6\end{array}$ & 1 & Oct. 13. & $\begin{array}{l}\text { Nymindegab, Denmark. } \\
\text { Solent. }\end{array}$ & $\begin{array}{l}600 \\
125\end{array}$ & $\begin{array}{r}237 \\
41\end{array}$ & $\begin{array}{l}2 \cdot 5 \\
3 \cdot 0\end{array}$ \\
\hline $\begin{array}{l}\text { XIV. } \\
\text { XV. }\end{array}$ & $\begin{array}{rr}, & 18 . \\
, \quad 23 .\end{array}$ & $\begin{array}{l}18 \frac{1}{2} \text { miles S.S. W. from Eddystone. } \\
(2 \text { miles to W.S. W. from XIII.) } \\
10 \text { miles W. } 3 \text { S. from Lizard Point. }\end{array}$ & $\begin{array}{l}6 \\
6\end{array}$ & $\begin{array}{l}2 \\
1 \\
2\end{array}$ & $\begin{array}{l}\text { June } 18 . \\
\text { May } 13 . \\
\text { Nov.10. }\end{array}$ & $\begin{array}{l}\text { Calais. } \\
\text { Calais. } \\
\text { Nymindegab, Denmark. }\end{array}$ & $\begin{array}{l}255 \\
255 \\
605\end{array}$ & $\begin{array}{r}120 \\
84 \\
265\end{array}$ & $\begin{array}{l}2 \cdot 1 \\
3 \cdot 0 \\
2 \cdot 2\end{array}$ \\
\hline $\begin{array}{l}\text { XVI. } \\
\text { XVII. }\end{array}$ & $\begin{array}{ll},, & 23 . \\
, & 23 .\end{array}$ & $\begin{array}{l}5 \text { miles S.S.E. from Wolf Rock. } \\
12 \frac{1}{2} \text { miles E. } \frac{1}{4} \text { S. from Start Light- }\end{array}$ & $\begin{array}{l}6 \\
6\end{array}$ & 1 & Mar. 3. & Porthleven Harbour, Cornwall. & 22 & 8 & $2 \cdot 7$ \\
\hline XVIII. & , 23. & $\begin{array}{l}\text { house. } \\
14 \text { miles from Start Lighthouse } \\
\text { (?S. ․ 3.). }\end{array}$ & 6 & 1 & Sep. 14 & Juist I., Germany. & 485 & 203 & $2 \cdot 3$ \\
\hline XIX. &, 24. & $\begin{array}{l}10 \text { miles S.S.E. from St. Mary's } \\
\text { Sound, Scilly Is. }\end{array}$ & 6 & & & & & & \\
\hline $\begin{array}{l}\mathrm{XX} \\
\mathrm{XXI}\end{array}$ & $\begin{array}{ll}, & 24 . \\
, & 24 .\end{array}$ & $\begin{array}{l}7 \frac{1}{2} \text { miles E. } \frac{1}{2} \text { S. from Eddystone. } \\
2 \text { miles W. } \frac{1}{4} \mathrm{~N} \text {. from Eddystone. }\end{array}$ & $\begin{array}{l}6 \\
6\end{array}$ & 1 & June 19. & Le Portel, near Boulogne, France. & 225 & 115 & $1 \cdot 9$ \\
\hline XXII. & ", 24. & 5 miles W.S.W. from Eddystone. & 6 & $\begin{array}{l}1 \\
2\end{array}$ & $\begin{array}{ll}\text { Mar. } 1 . \\
\text { Aug. } 5 .\end{array}$ & $\begin{array}{l}\text { Sharping Point, Bigbury Bay, Devon. } \\
\text { Le Portel, France. }\end{array}$ & $\begin{array}{r}20 \\
210\end{array}$ & $\begin{array}{r}5 \\
162\end{array}$ & $\begin{array}{l}4 \cdot 0 \\
1 \cdot 3\end{array}$ \\
\hline $\begin{array}{l}\text { XXIII. } \\
\text { XXIV. }\end{array}$ & Mar. 11. & 8 miles W. $\frac{3}{4}$ S. from Eddystone. & $\begin{array}{l}6 \\
6\end{array}$ & & & & & & \\
\hline $\begin{array}{l}\text { XXV. } \\
\text { XXVI. }\end{array}$ & $\begin{array}{ll}, & 11 . \\
, & 11 .\end{array}$ & $\begin{array}{l}2 \frac{1}{2} \text { miles S.S.E. from Rame Head. } \\
\frac{3}{4} \text { mile S.S.W. of Breakwater Light- } \\
\text { house, Plymouth. }\end{array}$ & $\begin{array}{l}6 \\
5\end{array}$ & 1 & Mar. 12. & $\begin{array}{l}\text { Whitsand Bay, Cornwall (between } \\
\text { Coastguard Station and Tregantle } \\
\text { Fort). }\end{array}$ & 4 & 1 & 4 \\
\hline $\begin{array}{l}\text { XXVII. } \\
\text { XXVIII. }\end{array}$ & $\begin{array}{rr}, & 15 . \\
1, & 31 . \\
1 & \text { a.m. }\end{array}$ & $\begin{array}{l}5 \text { miles S. W. from Eddystone. } \\
4 \text { miles W. } \frac{3}{4} \text { S. of Wolf Lighthouse. }\end{array}$ & $\begin{array}{l}6 \\
6\end{array}$ & & - & & & & \\
\hline
\end{tabular}




\begin{tabular}{|c|c|c|c|c|c|c|c|c|c|}
\hline \multirow{2}{*}{$\begin{array}{l}\text { No. of } \\
\text { Batch. }\end{array}$} & \multicolumn{2}{|r|}{ BOTTLES SENT ADRIFT. } & \multirow[b]{2}{*}{$\begin{array}{l}\text { No. of } \\
\text { Bottles. }\end{array}$} & \multicolumn{3}{|r|}{ BOTTLES RECOVERED. } & \multicolumn{3}{|c|}{$\begin{array}{l}\text { DISTANCE AND RATE } \\
\text { OF DRIFT. }\end{array}$} \\
\hline & Date. & Locality. & & $\begin{array}{l}\text { No. of } \\
\text { Bottle. }\end{array}$ & Date. & Locality. & $\begin{array}{l}\text { Minimum } \\
\text { distance } \\
\text { (Geog. } \\
\text { miles). }\end{array}$ & $\begin{array}{l}\text { Time } \\
\text { occupied } \\
\text { (days). }\end{array}$ & $\begin{array}{c}\text { Rate of } \\
\text { Drift } \\
\text { (miles } \\
\text { per day). }\end{array}$ \\
\hline XXIX. & Mar. 31. & Off Wolf Lighthouse (? E.S.E.). & 6 & & & & & & \\
\hline $\mathrm{XXX}$. & 4 a.m. & 8 miles N.E, by E. of Lizard. & 6 & 1 & $\begin{array}{l}\text { Apr. } 6 . \\
9 \text { a.m. }\end{array}$ & $\begin{array}{l}\text { Sennen Cove, near Land's End, Corn- } \\
\text { wall. }\end{array}$ & 35 & 6 & $5 \cdot 8$ \\
\hline XXXI. & Apr. 11 & 3 to 4 miles outside Eddystone. & 4 & 2 & $12-30$ p.m & Sennen Cove, near Land's End, Cornwall. & 35 & 6 & $5 \cdot 8$ \\
\hline XXXII. & ," 12. & 4 to 5 miles westwards of Eddystone. & 4 & $\begin{array}{l}1 \\
2\end{array}$ &,, 13. & $\begin{array}{l}\text { Windsworth, } 2 \text { miles E. of Looe, } \\
\text { Cornwall. }\end{array}$ & 10 & $1 \mathrm{~d} .3 \mathrm{~h}$. & $8 \cdot 8$ \\
\hline XXXIII. & ," 13. & 9 miles E. of Eddystone. & 6 & $\begin{array}{l}1 \\
2\end{array}$ & $\begin{array}{l}\text { Aug. } 22 . \\
\text { Oct. } 14 .\end{array}$ & $\begin{array}{l}\text { Chisel Beach, Dorset. } \\
\text { Oesterhever, Eiderstedt, Schleswig } \\
\text { Holstein, Germany. }\end{array}$ & $\begin{array}{r}77 \\
565\end{array}$ & $\begin{array}{l}131 \\
184\end{array}$ & $\begin{array}{r}\cdot 6 \\
3 \cdot 0\end{array}$ \\
\hline XXXIV. & , 16. & 3 to 4 miles S.W. of Eddystone. & 6 & $\begin{array}{l}1 \\
2\end{array}$ & $\begin{array}{l}\text { Aug. } 31 . \\
\text { Oct. } 14 \text {. }\end{array}$ & $\begin{array}{l}\text { Seaford, Sussex. } \\
\text { Wieringen I., Holland. }\end{array}$ & $\begin{array}{l}178 \\
415\end{array}$ & $\begin{array}{l}137 \\
181\end{array}$ & $\begin{array}{l}1 \cdot 3 \\
2 \cdot 2\end{array}$ \\
\hline XXXV. & , 21. & 2 miles E.S.E. of Wolf Rock. & 6 & $\overline{1}$ & $\begin{array}{r}\text { Feb. } 21 \\
1898 .\end{array}$ & Amrum I., Schleswig, Germany. & 643 & 306 & 2.1 \\
\hline XXXVIII. & ,, 22. & 10 miles W. $\frac{3}{4} \mathrm{~S}$. of Wolf Rock. & 6 & $\begin{array}{l}1 \\
2\end{array}$ & $\begin{array}{l}\text { May } 7 . \\
\text { June } 2\end{array}$ & $\begin{array}{l}\text { Bryher, Scilly Isles. } \\
18 \text { miles S.W. } \frac{3}{4} \text { S. of Bishop Light- } \\
\text { house, Scilly Isles. }\end{array}$ & $\begin{array}{l}15 \\
30\end{array}$ & $\begin{array}{l}15 \\
41\end{array}$ & $\begin{array}{l}1.0 \\
0 \cdot 7\end{array}$ \\
\hline $\begin{array}{l}\text { XXXIX. } \\
\text { XL. }\end{array}$ & M̈ay 11. & $\begin{array}{l}3 \text { to } 4 \text { miles S.W. of Eddystone. } \\
3 \text { miles E. } \frac{1}{2} \mathrm{~N} \text {. of Eddystone. } \\
\text { [Distance calculated to Croyde, then } \\
\text { back to Bude and Eastbourne.] }\end{array}$ & $\begin{array}{c}5 \\
18\end{array}$ & $\begin{array}{l}1 \\
1 \\
2 \\
3 \\
4 \\
5\end{array}$ & $\begin{array}{l}\text { Apr. } 25 . \\
\text { May } 27 . \\
\text { June } 2 . \\
\text {, } 22 . \\
\text { Aug. } 20 . \\
\text { Nov.17. }\end{array}$ & $\begin{array}{l}\text { Portscatho, Cornwall. } \\
\text { Mullion, Mounts Bay, Cornwall. } \\
\text { Penzance, Cornwall. } \\
\text { Croyde, N. Devon. } \\
\text { Bude, North Cornwall. } \\
\text { Eastbourne, Sussex. }\end{array}$ & $\begin{array}{r}25 \\
50 \\
60 \\
160 \\
190 \\
500\end{array}$ & $\begin{array}{c}3 \mathrm{~d} .1 \mathrm{~h} \\
16 \\
22 \\
42 \\
101 \\
190\end{array}$ & $\begin{array}{l}8 \cdot 2 \\
3 \cdot 1 \\
2 \cdot 7 \\
3 \cdot 8 \\
1 \cdot 8 \\
2 \cdot 6\end{array}$ \\
\hline XLI. &,, 25. & $\begin{array}{l}22 \text { to } 25 \text { miles S. by E. from Mew- } \\
\text { stone, Plymouth. }\end{array}$ & 2 & & & & & & \\
\hline
\end{tabular}




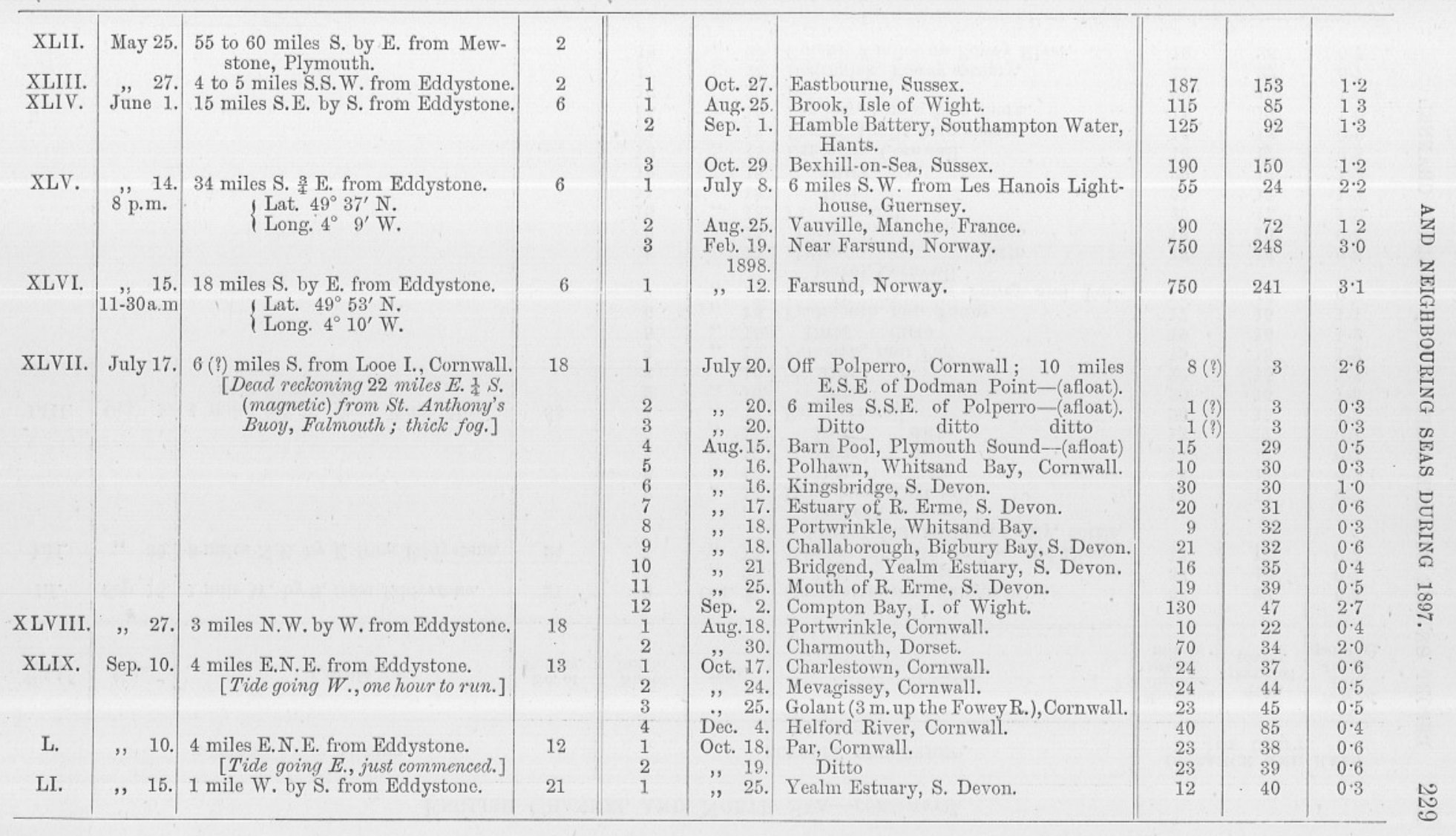




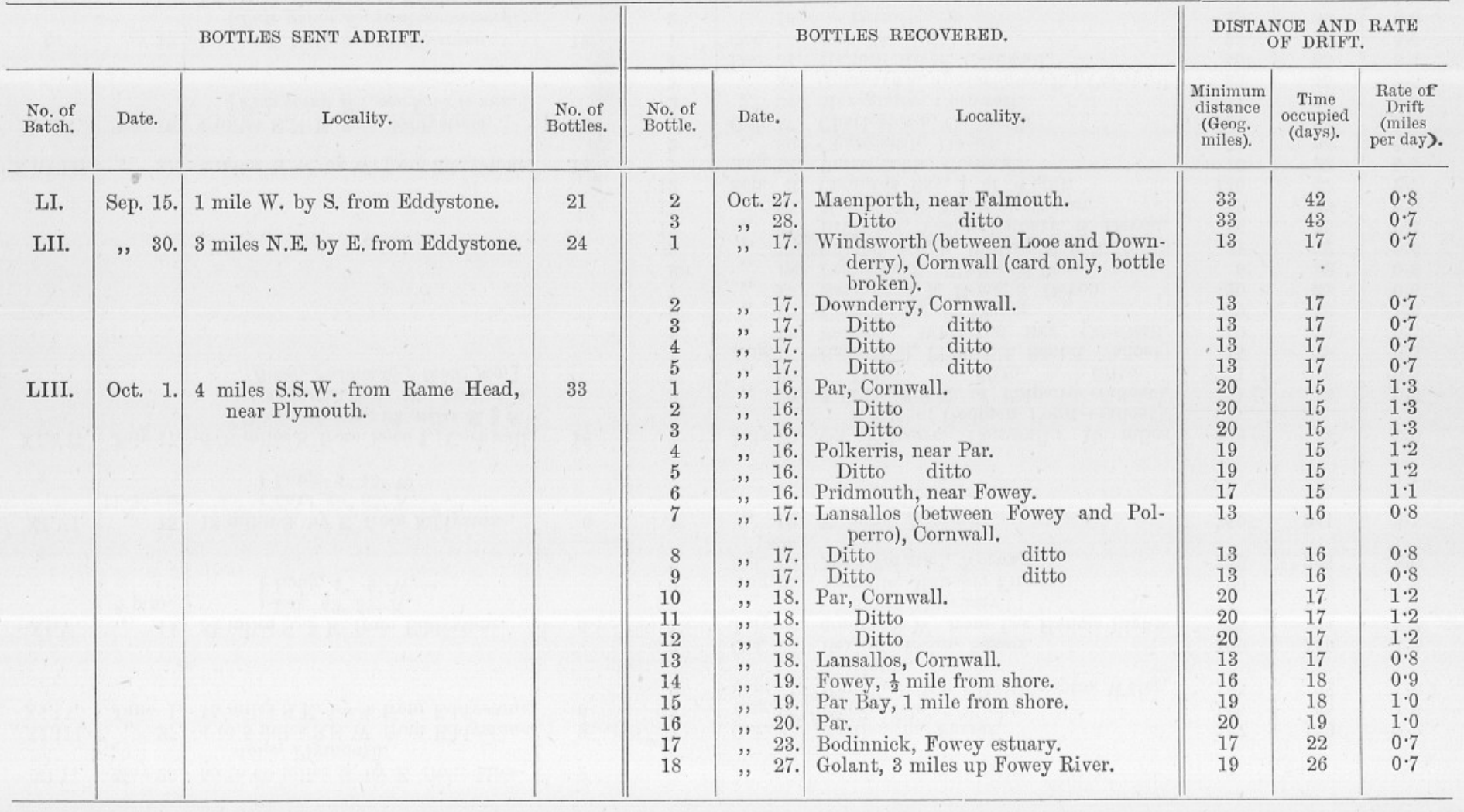


TABLE II.-ST. GEORGE'S CHANNEL AND IRISH SEA.

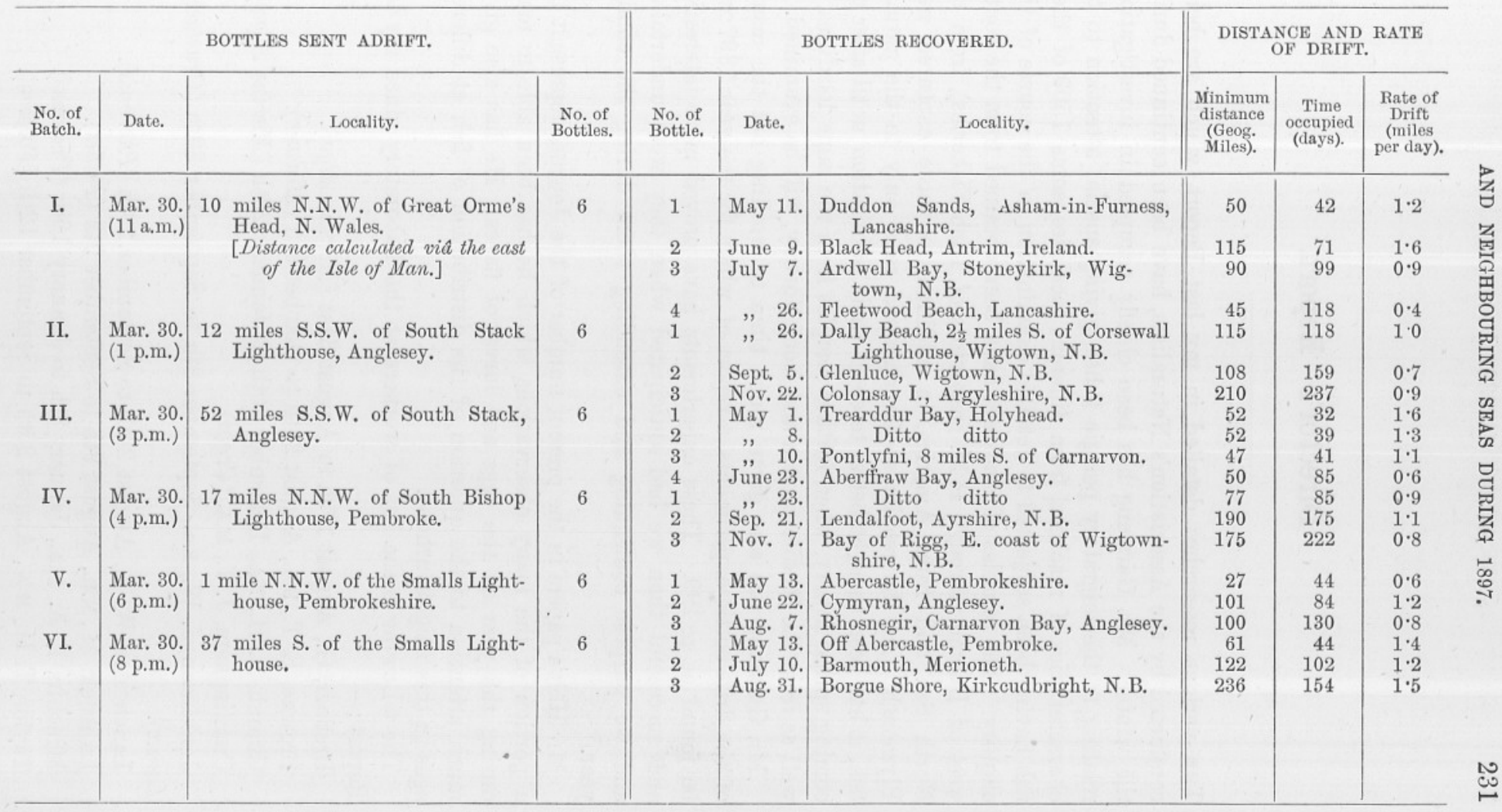

